\title{
Environmental Laws in Nigeria: Negligence and Compliance in the Building of Houses on Erosion and Flood Prone Areas in the South-South Region of Nigeria
}

\author{
Amen Osamede Jegede
}

\section{ABSTRACT}

This research work examined the assessment of Environmental Laws in Nigeria: Negligence and Compliance in the Building of Houses on Erosion and Flood Prone Areas in the South-South Region of Nigeria. Data for this study were collected from primary and secondary sources, through the administration of one thousand, seven hundred and twenty eight $(1,728)$ copies of questionnaire using the random sampling method on respondents. Simple percentages, charts, student's t-test, anova, and correlation statistical techniques were used in the analysis of the data collected. The results of the analysis revealed that $32.1 \%$ were in compliance; while $67.9 \%$ were non-compliance with environmental laws in the building of houses on erosion and flood prone areas in the South-South Region of Nigeria. The null hypothesis one was rejected in favour of the alternative hypothesis, which states that, there is a significant difference between the level of compliance in the building on erosion and flood prone areas within the study area. The study therefore recommends that, at present, all levels of Government should place more emphasis on the construction of flood and erosion control works, whenever there is flood and erosion menace. Although, the incorporation of the biological aspect with that of flooding and erosion control measures has proved to be somewhat effective, a more sustainable control of flooding and erosion problem should be advocated.

Keywords: Compliance, Effects, Environmental Laws, Erosion and Flooding

\section{INTRODUCTION}

The environment is the complex physical, chemical and biological factors/processes which sustain life [1]. The natural elements in the world both in the rural and urban environment, all have organic and inorganic realms. The inorganic realms are the atmosphere, the hydrosphere and the lithosphere [2], while the organic realm is the biosphere. According to [3] the environment is itself, the point in which one is found at a time, the surroundings, the more distant places, other earth components, conditions, prospects and problems which account for its flourishing or otherwise. In general, the environment provides all life support systems in the air, water, on land and in the forests [4].

Environmental problems therefore manifest as a result of different land use activities of man to earn his living and his livelihood. In the urban land use, deforestation has become a peculiar problem in Nigeria particularly in the South-South Region of the country, which results from uncontrolled logging and tree felling, for the purpose of urban development. In many parts of the southern states of Nigeria, this goes with its loss of precious biological diversity.

There is a growing global concern for the preservation and conservation of the environment. This is because of the realization that every human being has the right to environmental protection coupled with the quality and standard of human life and healthcare that a person enjoys. Furthermore, the survival of man depends entirely on the survival of the environment from which mankind derives his livelihood [5]. Thus, law and policy makes environmental protection works. It is the government and relevant agencies that possess the capacity and ability to make policies and back it up with laws to effect environmental compliance. The Federal Environmental Protection Agency was set up in 1988 by virtue of Act No 58 of 1988 . The agency is a corporate body with perpetual succession and a common seal, and may sue and be sued in its corporate name [6].

In Nigeria, an environment is by statute defined to include water, air, land and all plants and human beings or animals living therein and the interrelationships which exist among these or any of them [7].

According to [8] he agreed with this definition, according to him, Nigerian environment is composite in nature. This means that, an environment is the aggregate of social and cultural condition that influence the life of an individual or community. In-view of the fact that the environment is the most formidable source of national and international development; it must be protected from damage, destruction, or annihilation. Since an abuse of the environment could result in its decay which will ultimately affect meaningful development, there is therefore the need to preserve the ecosystem.

Since the early 1970s, there has been increased awareness and consciousness about environmental issues at all levels, this is due to the prevailing environmental problems all over the world [9]. At the global level, the United Nations and other multi-lateral organizations have, through notable 
global fora, provided the milestones and benchmarks for new directions in formulating policies on the preservation of the integrity of the ecosystem and human wellbeing. The result has been the creation of institutional arrangements and mechanisms for environmental management at global and regional levels. They have also encouraged national Governments to create institutions for the protection of the environment and human health.

\section{STATEMENT OF THE PROBLEM}

According to a report by [10), Nigeria is endowed with a large natural wealth, which contributes to the economic development and social well-being of the country. In spite of this, much of the environmental and natural capital is being lost every year owing to population growth, economic activities, lack of environmental considerations and policy failures. [11] equally noted that every year, environmental degradation costs the Nigerian economy between 5 and 10 percent of the Gross Domestic Product (GDP) with a mean estimate of 8 percent. Damages from indoor air pollution accounts for between 1 and 2 percent of the Gross Domestic Product (GDP) making it a major cause of death in Nigeria.

Every year, on the average, nearly 50,000 children under the age of 5 die, due to acute respiratory illnesses linked to household smoke. Lack of water and sanitation and poor hygiene are also important; on the average, diarrhea alone kills every year, 30,000 children less than 5 years of age. Consequently, Nigeria may not be able to meet the Millennium Development Goals of water and sanitation by 2015. The national environmental problems are compounded by unsound wastes management practices. Waste management problems in Nigeria are varied and complex with infrastructure, political, technical, social/economic and organizational/management, regulatory and legal issues and challenges to be addressed.

The country urgently needs infrastructural, institutional, legal and attitudinal reforms to tame the waste monster, and adopt Environmentally Sound Management (ESM) of waste (including Waste Minimization, focusing on the promotion of the " 3 Rs" Reduce, Reuse and Recycle), Waste to Wealth initiatives towards poverty reduction and alleviation; Corporate Social Responsibility by producers of wastes; and, not the least involvement of multi-stakeholders e.g. under the New Partnership for Africa Development (NEPAD) initiative [11].

Industries are the single largest group of polluters of any nation's environment and gobblers of the national resources used as raw materials [5]. As energy consumption increases with increase in industrialization, it is essential to ensure a balanced mix of various energy, which will be compatible with sound environmental practice and the reduction of the negative impact of energy production and use on the environment.

[12] observed that no laws can save nature. It is only man himself that can do it. So, we have to change ourselves to protect nature and environment. Indeed, it must be clear to all that legislations on environmental protection, such as the Environmental Impact Assessment (EIA) in the form of global, regional or domestic instruments, are not an end in themselves and cannot save the environment, although legislations are important and necessary. [13] stated that every environmental legislation in Nigeria aimed at sustainable development in resource exploitation and management like laws, must consider the problems of industries, mining, forestry, rural and urban dwellers in a holistic manner for the achievement of maximum potentials for all.

The South-South Geo-political Zone of Nigeria is blessed with both human and material resources, but the unfavorable manner in which these resources are harnessed overtime, is the bane of the regions predicament [14]. It was further stressed that before the discovery of crude oil, agriculture was the dominant occupation of the people. Crude oil was discovered in commercial quantity in the region specifically in the present Bayelsa State in 1956 [15]. Since then, oil exploration and exploitation has continued resulting into what is termed environmental destruction due to neglect and less concern of the multinational companies in environmental management in the area.

\section{AIM AND OBJECTIVES OF THE STUDY}

The main aim of this study was to examine the spatial variation in the compliance and non-compliance of environmental laws in the building of houses on erosion and flood prone areas in the South-South Region of Nigeria.

The specific objectives of this study were to:

i. map the areas of compliance and non-compliance of environmental laws in the building of houses on erosion and flood prone areas within the study area

ii. assess the areas of compliance and non-compliance of environmental laws in the building of houses on erosion and flood prone areas.

iii examine the immediate causes in the building of houses on erosion and flood prone areas in the South-South Region of Nigeria

iv identify the impacts of flooding and erosion menace on housing facilities in the study area

$\mathrm{v}$ recommend possible remedial measures on environmental problems which emanates from the negligence of environmental laws, as well as strengthen the existing environmental laws in the study area.

\section{HYPOTHESES OF THE RESEARCH STUDY}

For the purpose of this study, the following working hypotheses have been developed in line with the objectives of the study stated earlier.

i) There is no significant difference between the maps produced from erosion and flood prone areas within the study area.

ii) There is no significant difference from the assessment of compliance and non-compliance of environmental laws in the building of houses on erosion and flood prone areas within the study area.

iii) There are no significant causes of erosion and flooding in the study area

iv) There is no significant impact of flooding and erosion menace in the study area

\section{THE STUDY AREA \\ A. Components and Location}

The South-South Geo-political Zone of Nigeria is made up of six states; these are Edo, Delta, Bayelsa, Rivers, AkwaIbom and Cross River States (Figs 1 and 2).

\section{B. Climate}

South-South Geo-political Zone of Nigeria has two seasons. These are the dry season and wet season. The dry season is accompanied by a dust laden air-mass while the wet season 
is heavily influenced by an air-mass originating from the South Atlantic Ocean.

\section{Drainage}

The South-South Geo-political Zone of Nigeria is a lowlying region through which the waters of the Niger River drain into the Gulf of Guinea. Characteristics landforms in this region include ox-bow lakes, river meander belts (Niger Delta, 2011) and prominent levees. Large fresh water swamps give way to brackish mangrove thickets near the sea-coast. River Ethiope and Ikpoba River are important river in the area known for fishing and water transportation activities. The South-South Region of Nigeria stretches for nearly $177 \mathrm{~km}$ (110 miles) from North to South and spread along the coast for about $257.4 \mathrm{~km}$ (160 miles) [16]. Within the Delta, River Ethiope breaks up into an intricate network of channels called rivers. The Nun River is regarded as the direct continuation of River Ethiope and Ikpoba River [17].

\section{Vegetation}

The vegetation in the South-South Geo-political Zone of Nigeria, consist mainly of forest swamps. The forests are of two types, nearest the sea is a belt of saline/brackish mangrove swamp separated from the sea by sand beach ridges within the mangrove swamp. Numerous sandy islands occur with fresh water vegetation. Fresh water swamps gradually supersede the mangrove on the landward side [16].

\section{E. $\quad$ Natural Resources}

Nigeria is regarded as the sixth largest oil producing country in the world today, due to the large volume of crude oil deposit in the South-South Region of Nigeria. Other solid mineral deposits in the South-South Region of Nigeria are industrial clay, silica, lignite, kaolin, tar, sand, decorative rocks, limestone etc. [18]. These are raw materials for industries such as brick making ceramics, bottle manufacturing, sanitary wares and gas produces about $70 \%$ of Nigeria's income.

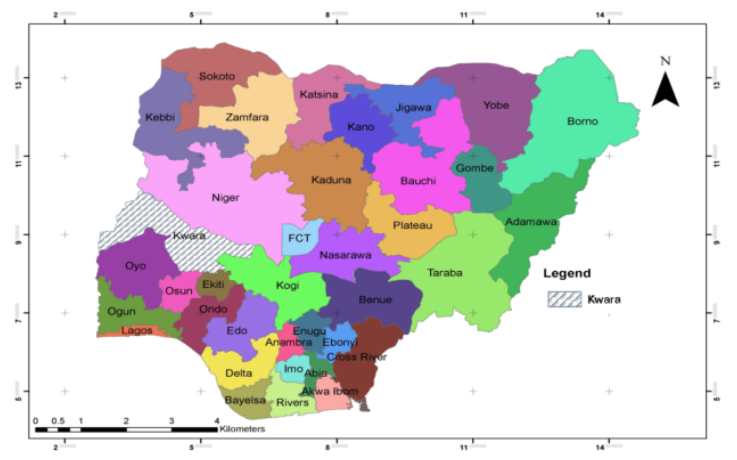

Figure 1.1: Map of Nigeria

Source: Kwara State Office of the Surveyor General, 2018

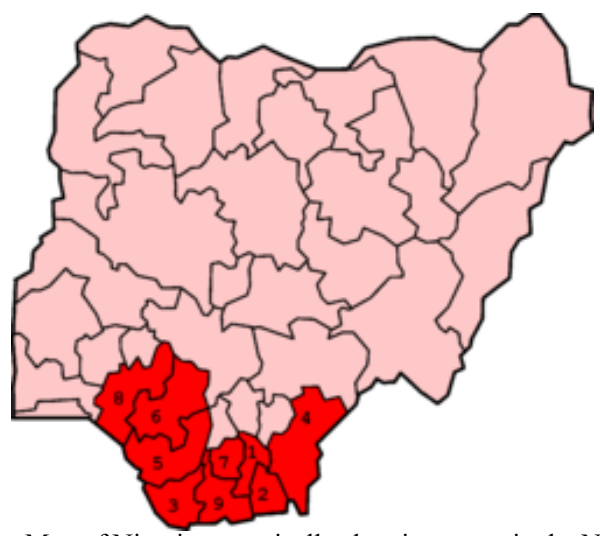

Figure 1.2: Map of Nigeria numerically showing states in the Niger Delta and The South-South Region of Nigeria Source: Author's Fieldwork, 2020

\section{THEORETICAL FRAMEWORK / LITERATURE REVIEW}

The Concept of Sustainable Development is equally applicable to this study. The concept of sustainable development is contained in the Brundtland Report of the United Nations Commission on Environment and Development (1987). [19] defined sustainability as the intensified and equitable conservation in the use of land, water, marine and coastal resources resulting from the expansion of agriculture and uncontrolled urbanization leading to increased degradation of natural resources and promoting their sustainable use in an essential response of the world community to ensure its own survival and wellbeing.

Development as defined by [20] is a comprehensive economic, cultural and political process, which aims at the constant improvement of the well-being of the entire population and of all individuals on the basis of their active, free and meaningful participation in development and in the fair distribution of benefits resulting there from.

The most popular definition appears to be contained in the Brundtland Report of the United Nations Commission on Environment and Development in (1987) which defined the concept as, "developments that meet the needs of the present without compromising the ability of future generations to meet their own needs". In essence, the objectives of the concept of sustainable development include ensuring that there are enough resources for the human population as a whole, that these resources are distributed to benefit as many people as possible and that the environment be developed, while protecting the environment for the benefit of all present and future generations.

Indeed, the concept of sustainable development has been expanded to encompass four interpretations as follows:

The need to preserve environmental resources for the benefit of future generations. The need to exploit environmental resources in a manner, which is sustainable or prudent (the principle of sustainable use). The equitable use of environmental resources by taking into consideration the environmental needs of other people to the use and enjoyment of the scarce or finite environmental resources. The need to ensure that environmental activities are integrated into the economics of environmental laws and its attendant effects on development plans, an also the inclusion of development needs in the application of environmental objective.

The concept of sustainable development is applicable to this study in that, the legal origin of the concept of 
sustainable development can be traced to the earliest efforts of man to protect the right of others to the use and enjoyment of environmental resources in the form of property rights or environment. This legal protection is expressed in the maxim, 'sic utere tuo at in alienum non leadas', which translates as 'so use your own as not to harm another'. Therefore, where and when there is collective compliance of the people with environmental laws, the available natural and human resources in the area will be sustained, since actions that degrade the environment will be drastically minimized, if not completely put an end to.

[21] discovered that international environmental laws on environmental problems have greatly contributed to the development of municipal laws by the countries that are signatories to some of the convections and the protocols made thereto. United Nations (2009) further noted that the treaties have become the source of law on environmental issues in many of the countries by domesticating them. Nations of the world have come to realize that they have a common stake in the protection of the global environment and that it is one of the best means of resolving bilateral or multilateral agreements.

[5] opined that environmental laws has been playing significant roles and will continue to play active roles on environmental issues. In addition to its traditional roles in the formulation of national and international policies on the environment, it has helped in translating concrete actionable instruments and translating scientific information on the environment into obligatory norms and rules. [22] stated that environmental laws helped to focus attention on the existence of global environmental problems and the need for international solutions to these problems. It has also played pioneering roles in the formulation of legal principles (e.g. the sustainable development and the precautionary principle) which become the basis for world environmental order [22].

\section{RESEARCH METHODS}

\section{A. Research Design}

The research design for this study was based on the careful gathering, analysis and application of facts in order to achieve the stated objectives and to test the acceptability or otherwise of the hypotheses stated in this study.

\section{B. Data Type and Sources}

\section{i. Primary Data}

Geographic Information System (GIS) and the underlying thematic mapping arc-view device were applied, as well as the administration of questionnaires (See Appendix 1). The first stage was the procurement of the maps of the six states in the South-South Geo-political Region of Nigeria (AkwaIbom, Bayelsa, Cross River, Delta, Edo and Rivers States) which is the coverage area for this study. From the six states in the South-South Region, one Local Government Area was selected from each of the eighteen Senatorial Districts using stratified sampling technique (See Table 1.).

Remotely Sensed Imagery combined with scientific visualization and digital cartography was applied in the mapping and assessment of erosion and flood prone areas within the study area.

A 49-item Questionnaire was administered to elicit useful information from categories of respondents on environmental problems which emanate from the building of houses on erosion and flood prone areas, extraction of crude oil by oil companies, existing road transportation land use pattern, as well as health hazards which emanates from waste dumpsites in the study area. A total number of one thousand, eight hundred $(1,800)$ copies of questionnaire were administered in this research; one hundred (100) copies of the questionnaire were administered to each of the randomly selected 18 Local Government Areas in the six states in the South-South Region of Nigeria. The one thousand eight hundred $(1,800)$ copies of questionnaires were administered within the space of two (2) months in the 18 randomly selected Local Government Areas in the SouthSouth Region of Nigeria. The questionnaires were administered by the researcher and 18 research assistants domiciled in the randomly selected 18 Local Government Areas. Copies of the questionnaires were administered during working days from Mondays to Thursdays and retrieved every Friday from civil servants and public servants in their offices in the study area. Copies of questionnaires administered on market men and women were administered daily and retrieved the following day. Why copies of questionnaires administered on members of the National Union of Road Transport Workers (NURTW) were done on daily basis from Monday to Friday and collected on Saturday, with the assistance and co-operation of the Union Chairmen. Out of which, one thousand seven hundred and twenty eight $(1,728)$ copies of the questionnaires were retrieved from the field, making it $96 \%$ retrieval rate. Seventy-eight (78) copies of the questionnaire; which is $4 \%$ of the questionnaire were either mis-placed or mistakenly torn by the respondents.

Table 1: States Surveyed

\begin{tabular}{|l|l|l|}
\hline & Frequency & Percentage \\
\hline Akwa-Ibom & 280 & 16.2 \\
\hline Bayelsa & 287 & 16.6 \\
\hline Cross River & 294 & 17.0 \\
\hline Delta & 291 & 16.8 \\
\hline Edo & 292 & 16.9 \\
\hline Rivers & 284 & 16.4 \\
\hline Total & 1728 & 100.0 \\
\hline
\end{tabular}

Table 1 shows that $16.2 \%$ of the respondents were from Akwa-Ibom State, $16.6 \%$ of the respondents were from Bayelsa State, $17.0 \%$ of the respondents were from Cross River State, $16.8 \%$ of the respondents were from Delta State, $16.9 \%$ of the respondents from Edo State and $16.4 \%$ of the respondents were from Rivers State. This indicates that the response of the respondents were considerably very high and reliable, since the total returned rate of the questionnaires administered was $96.0 \%$. This tells us that the data generated from this research work is reliable.

\section{ii. Secondary Data}

The secondary source of data collected in this study were collected on pipeline vandalization, illegal bunkery activities, oil explosion and spillage within the study area from the office of the National Oil Spill Detection and Response Agency (NOSDRA).

The data which were obtained in the study area were subjected to statistical analysis using descriptive and inferential statistical tools and these include the use of maps, tables, charts, and graphs, while the Student's t-test, Analysis of Variance and Spearman Rank Correlation Coefficient were used as inferential statistical tools to test the stated hypotheses.

C. Method of Data Analysis 
The Statistical Package for Social Sciences (SPSS) was used in the descriptive analysis of the data collected in this research work. This was done by describing and comparing areas of compliance and non-compliance of environmental laws in the building of houses on erosion and flood prone areas, environmental problems which emanate from the compliance and non-compliance of environmental laws through the exploration and extraction of crude oil activities in the area, transportation land-use pattern within the study area, compared with the urban master plan and the assessment of the potency of waste dumpsites health hazards on the immediate environment.

The descriptive analysis was employed for the analysis of hypothesis one (1) the significant differences between maps produced from erosion and flood prone areas within the study area.

Inferential Analysis: This was employed for hypothesis two (2) to five (5). The statistical tests used were student t-test, Analysis of Variance (ANOVA) and Pearson Product Moment Correlation Coefficient (PPMCC).

\section{RESULTS AND DISCUSSIONS}

Table 2: Causes of Flooding in the Study Area

\begin{tabular}{|l|l|l|}
\hline & Frequency & Percentage \\
\hline $\begin{array}{l}\text { Absence or ineffective } \\
\text { drainage channels }\end{array}$ & 501 & 28.9 \\
\hline High intensity of rainfall & 210 & 12.2 \\
\hline $\begin{array}{l}\text { Negligence of building } \\
\text { approval plans }\end{array}$ & 246 & 14.3 \\
\hline $\begin{array}{l}\text { Building of houses or } \\
\text { structures on river } \\
\text { channels/route networks }\end{array}$ & 444 & 25.7 \\
\hline $\begin{array}{l}\text { Illegal dumping of refuse } \\
\text { on drainage channels }\end{array}$ & 327 & 18.9 \\
\hline Total & 1728 & 100.0 \\
\hline
\end{tabular}

Table 2 shows that $28.9 \%$ of the respondents in the study area stated that, the cause of flooding in their area is absence or ineffective drainage channels, $12.2 \%$ noted high intensity of rainfall, $14.3 \%$ stated negligence of building approval plans, $25.7 \%$ observed building of houses on river channels or route networks, $18.9 \%$ of the respondents stated illegal dumping of refuse on drainage channels. This suggests that the major cause of flooding in the area is absence or ineffective drainage system. Thus, more drainage systems need to be provided and the available drainage system rehabilitated to reduce the problem of flooding in the area.

Table 3. Effects of Flood on Houses/Properties/Offices

\begin{tabular}{|l|l|l|}
\hline & Frequency & Percentage \\
\hline Yes & 1032 & 59.7 \\
\hline No & 696 & 40.3 \\
\hline Total & 1728 & 100.0 \\
\hline
\end{tabular}

Table 3 reveals that $59.7 \%$ of the respondents indicated that flood had affected their properties in the area, $40.3 \%$ of the respondents stated that flood had not affected their property in the area. The implication of this is that majority of the inhabitants within the study area had suffered from the problems of flooding, due to its high incidence in the area.

Table 4: Solution to Flood Problems in the Study Area Frequency Percentage

\begin{tabular}{|l|l|l|}
\hline Public enlightenment campaign & 312 & 18.0 \\
\hline $\begin{array}{l}\text { Adequate compliance to the } \\
\text { environmental laws }\end{array}$ & 486 & 28.1 \\
\hline Bringing offenders to book & 366 & 21.2 \\
\hline $\begin{array}{l}\text { Provision of adequate funds to } \\
\text { redress the problems. }\end{array}$ & 228 & 13.3 \\
\hline $\begin{array}{l}\text { Intervention of personnel in the } \\
\text { Ministries of Environment and } \\
\text { Town Planning. }\end{array}$ & 336 & 19.4 \\
\hline Total & 1728 & 100.0 \\
\hline
\end{tabular}

Table 4 shows that $18.0 \%$ of respondents stated that the solution to flood problems in the area was public enlightenment campaign, $28.1 \%$ noted compliance to the environmental laws, $21.2 \%$ stated bringing offenders to book, $13.3 \%$ observed provision of adequate funds to redress the problems, while $19.4 \%$ of the respondents noted the intervention of personnel in the ministries of environment and town planning. This suggests that the best approach to redress environmental problems in the study area was the adoption of adequate compliance to the environmental laws.

Table 5.Erosion Problems in the Study Area

\begin{tabular}{|l|l|l|}
\hline & Frequency & Percentage \\
\hline Yes & 1086 & 62.8 \\
\hline No & 642 & 37.2 \\
\hline Total & 1728 & 100.0 \\
\hline
\end{tabular}

Table 5; reveals that $62.8 \%$ of the respondents stated that there was erosion problems in their area, $37.2 \%$ of the respondents noted that erosion problems were not conspicuous in their area. This implies that the problem and features of erosion is very high and at so many places in the study area. Again, flooding and erosion features were highest in Rivers and Bayelsa State respectively; due to the water logged nature of the area, streams and river, which are virtually everywhere, higher in comparison to Delta State, Akwa-Ibom State, Cross River State and Edo State in this order.

Table 6: Causes of Erosion in the Study Area

\begin{tabular}{|c|c|c|}
\hline & Frequency & Percentage \\
\hline $\begin{array}{l}\text { Building of houses on natural } \\
\text { routes }\end{array}$ & 501 & 20.3 \\
\hline Deforestation & 261 & 15.1 \\
\hline $\begin{array}{l}\text { Deposition of refuse on } \\
\text { drainage channels }\end{array}$ & 408 & 23.6 \\
\hline $\begin{array}{l}\text { Ignorance on the consequences } \\
\text { of erosion }\end{array}$ & 207 & 12.0 \\
\hline $\begin{array}{l}\text { Negligence/violation of } \\
\text { environmental laws }\end{array}$ & 351 & 29.0 \\
\hline Total & 1728 & 100.0 \\
\hline
\end{tabular}

Table 6 , shows that $20.3 \%$ of the respondents stated that the cause of erosion in their area was the building of houses on natural routes, $15.1 \%$ stated deforestation, $23.6 \%$ noted deposition of refuse on drainage channels, $12.0 \%$ stated ignorance on the consequences of erosion, $29.0 \%$ observed negligence/violation of environmental laws. This implies that the major cause of erosion in the study area was the negligence/violation of environmental laws. Thus, activities that result to the problems of erosion in the study area such 
as dumping of refuse on drainage channels, poor road construction and haphazard location of housing units etc should be avoided as much as possible.

Table 7: Resultant Effects of Flooding and Erosion Menace in the Study Area.

\begin{tabular}{|l|l|l|}
\hline & Frequency & Percentage \\
\hline $\begin{array}{l}\text { Slow vehicular } \\
\text { movement/traffic jam }\end{array}$ & 360 & 20.8 \\
\hline Accident & 390 & 22.6 \\
\hline $\begin{array}{l}\text { Collapse buildings \& } \\
\text { other infrastructural } \\
\text { facilities }\end{array}$ & 276 & 16.0 \\
\hline $\begin{array}{l}\text { Lack of access to other } \\
\text { areas }\end{array}$ & 702 & 40.6 \\
\hline Total & 1728 & 100.0 \\
\hline
\end{tabular}

Table 7 shows that $20.8 \%$ of the respondents stated that the resultant effect of flooding and erosion menace in their area was slow vehicular movement/traffic jam, $22.6 \%$ of the respondents stated increased accident rate, $16.0 \%$ of the respondents observed collapsed of buildings and other infrastructural facilities, while $40.6 \%$ of the respondents observed lack of access to other environment/areas. The most grievous of these is the lack or poor access to neighbourhoods /towns /areas, due to the effect of flooding and erosion menace in the study area.

Table 8: Adequate Knowledge of Environmental Laws

\begin{tabular}{|l|l|l|}
\hline & Frequency & Percentage \\
\hline Yes & 1077 & 62.3 \\
\hline No & 651 & 37.7 \\
\hline Total & 1728 & 100.0 \\
\hline
\end{tabular}

Table 8 shows that $62.3 \%$ of the respondents stated that they have good knowledge of environmental laws, while $37.7 \%$ of the respondents stated that they do not have adequate knowledge of environmental laws in the study area. This suggests that majority of the respondents in the study area were enlightened, and as such useful in providing information on the subject matter in the area.

Table 9: Environmental Problems Experienced in the Area.

\begin{tabular}{|l|l|l|}
\hline & Frequency & Percentage \\
\hline $\begin{array}{l}\text { Flooding and } \\
\text { erosion }\end{array}$ & 873 & 50.5 \\
\hline $\begin{array}{l}\text { Indiscriminate } \\
\text { waste disposal }\end{array}$ & 279 & 16.1 \\
\hline $\begin{array}{l}\text { Pollution from gas } \\
\text { flaring/oil } \\
\text { explosion \& } \\
\text { spillage }\end{array}$ & 258 & 15.0 \\
\hline Poor road networks & 318 & 18.4 \\
\hline Total & 1728 & 100.0 \\
\hline
\end{tabular}

Table 9, shows that $50.5 \%$ of the respondents stated that the major environmental problem experienced in their area was flooding and erosion, $16.1 \%$ of the respondents stated indiscriminate waste disposal, $15.0 \%$ of the respondents stated pollution from gas flaring/oil explosion and spillage, $18.4 \%$ stated poor road networks. This suggests that the major environmental problems that have mostly affected the people in the study area were flooding and erosion. Thus, the level of non-compliance of environmental laws in addressing the causes and problems of flooding and erosion in the study area is considerably very high.

\section{A. Discussions}

\section{i. Physical Survey Analysis}

The physical survey of some randomly selected sites within the study area was carried-out to obtain and physically observe the level of compliance and non-compliance of environmental laws in the building of houses on erosion and flood prone areas, problems of flooding and erosion on the existing road transportation land-use pattern within the study area and the level of compliance with the urban master plan. Also, environmental problems, which emanate from the non-compliance of environmental laws through the extraction of crude oil by the oil companies and assess waste dumpsites in the study area and the impacts of their health hazards on the immediate environment. The following observations" were noted.

\section{ii. Earth Road Affected by Flooding and Erosion}

It was discovered during the physical survey of some of the streets among the Local Government Areas randomly selected (Abak, Ibiono-Ibom, Ekeremor, Brass, Ikom, Ogoja, Burutu, Udu, Egor, Igueben, Oredo, Bonny and Eleme Local Government Areas) within the study area, some of the roads surveyed were found to be in dilapidated conditions, in which, the earth roads or untarred roads were covered with flooding and erosion features, setting in to obstruct free flow of vehicles and pedestrian movement in the areas. This resulted from the non-compliance of environmental laws and deviation from the urban master plan in the study area. Some of the houses around the flooded road network were majorly four (4) metres, three (3) metres and two (2) metres set-back from the road, which were not in compliance to environmental laws in the construction of housing units, which states that a housing unit should be erected at least six (6) metres set-back from the road transport routes. See plates $i \& i i$.

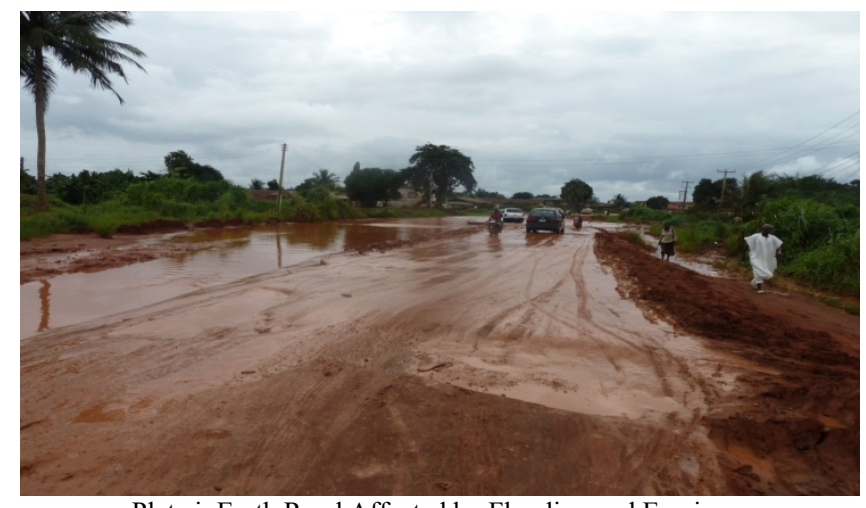

Plate i: Earth Road Affected by Flooding and Erosion. 


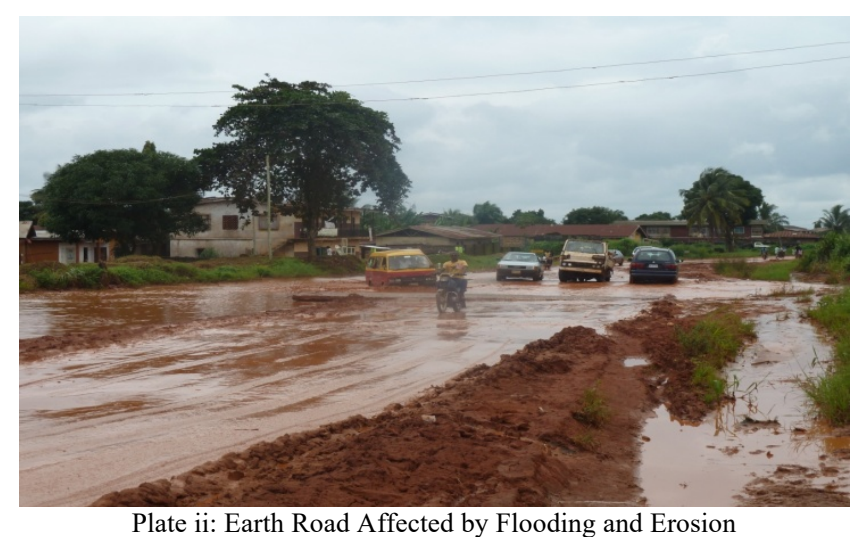

Plate ii: Earth Road Affected by Flooding and Erosion

\section{Building of Houses on Erosion and Flood Prone Areas}

It was discovered in the study area that several houses/buildings have been abandoned due to the problems of erosion and flooding. Some of the houses were already sub-merging, covered with grasses and almost in unrecoverable condition. Traces of rill and gully erosion were seen as leading routes to the buildings. These were as a result of non-compliance to environmental laws, such as wrong planning, none or poor construction of drainage channels along the road network, building of houses on natural routes or route channels and building of houses on floodable areas. The housing units affected by the problem of flooding and erosion in Etuk Street; Ibiono-Ibom Local Government Area of Akwa-Ibom State were twenty one housing units. Also, the number of houses affected by the problems of flooding and erosion in Street, Oshimili Local Government Area of Delta State were twenty six housing units. While, the number of housing units affected by the problem of flooding and erosion in Ogida Street; Egor Local Government Area of Edo State were eighteen housing units. See plates iii, iv \& $v$.

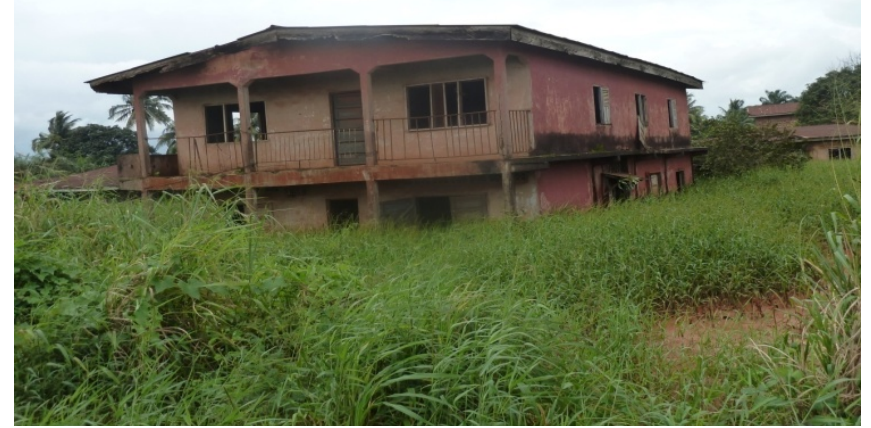

Plate iii: Abandoned Storey Building, due to flooding and erosion problem in Ibiono Ibom Local Government Area of Akwa-Ibom State.

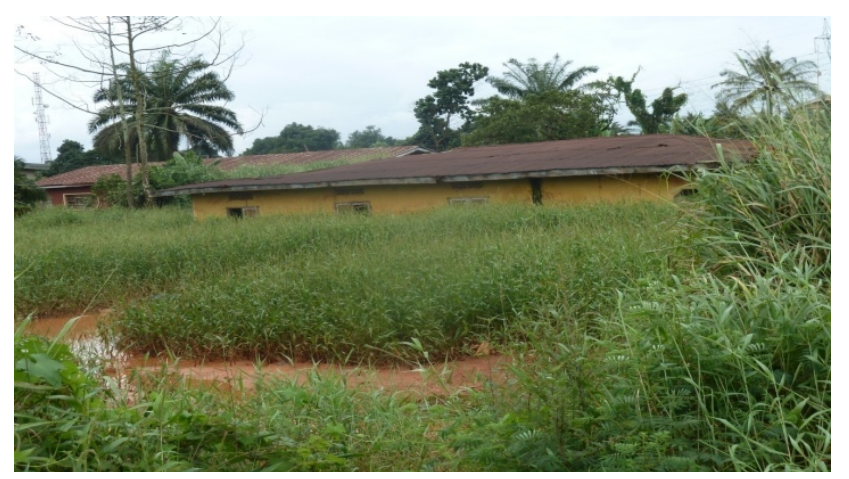

Plate iv: Abandoned buildings due to flooding and erosion problem in Oshimili South Local Government Area of Delta State.

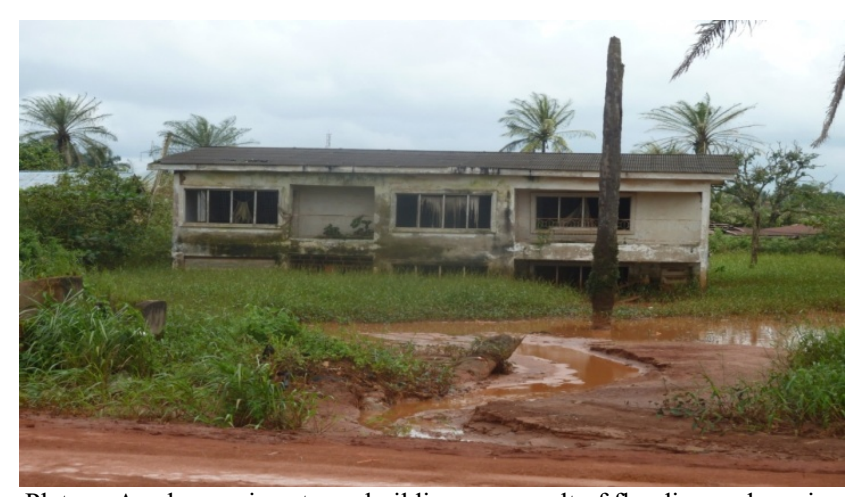

Plate v: A sub-merging storey building as a result of flooding and erosion problem in Egor Local Government Area of Edo State.

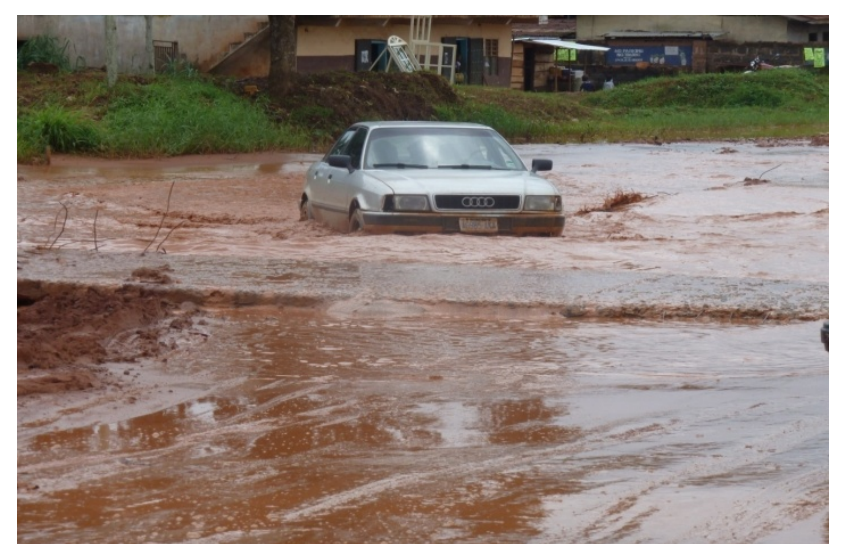

Plate Xi: A Stranded Vehicle at the Middle of a Road in Burutu Local Source: Fieldwork, 2012.

The condition of some of the road transport routes in the area were found to be in a deplorable condition, when and where transporters on buses, cars and motorcycles struggled to ply the roads. This is due to the volume of flooding and erosion that has dilapidated the road transport networks, wasting man hours and causing break down of vehicles. The problem is escalated by undue expansion of the road networks, as a result of flooding and erosion; wearing and tearing away, the initial structure of the road networks. See plate xi, xii, xiii \& $x v$.

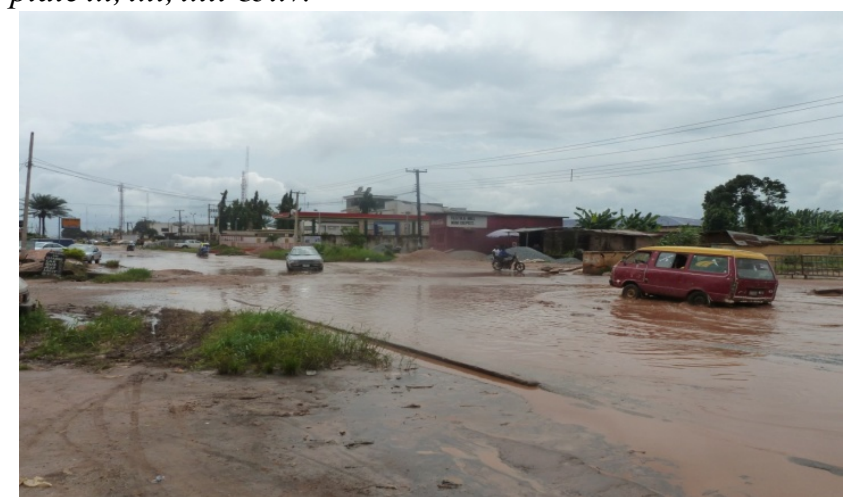

Plate xii: Abandoned Public Transport Bus along the Road Due to the Problems of Flooding and Erosion in Benin City, Edo State. 


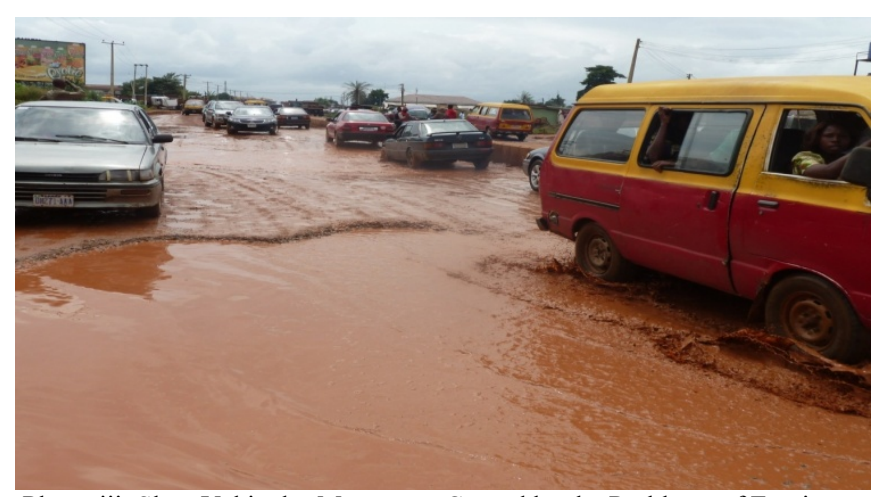

Plate xiii: Slow Vehicular Movement Caused by the Problems of Erosion and Flooding on the Road Network

\section{RECOMMENDATIONS}

In view of the findings in this study, it will be of great benefits, if the following recommendations are given serious attention and consideration. In our pursuit of a new mechanism for environmental protection, we must strive towards achieving a balance in the benefits we derive from activities that cause environmental pollution and the resultant harm.

It is imperative to identify high-risk and priority areas for environmental protection and clean-up. The establishment of environmental mechanism to monitor and assist or, where expedient, direct the response, including mobilizing the necessary resources to save lives, protect threatened environment and clean up to the best practical extent of the impacted areas should be of utmost concern to Government at all levels in the study area.

Strict environmental laws should be legislated, to ensure an appreciable participation in the general environmental sanitation, as well as to bring violators to book in the area. The enforcement mechanism should involve visits to facilities for compliance monitoring, facilities work through, finding-out challenges for non-compliance, examining monitoring records where they exist, undertaking in-situ environmental monitoring of some parameters and discussing findings with the faculty manager and proffer appropriate advice, that could promote compliance or issue warning, where non-compliance is persistent.

Adequate resources are required for effective industrial inspectorate, which includes trained inspectors, support equipment, functional administration system, functional and well equipped laboratory with trained personnel, while permit and penalty fees can be used to cover the costs of the inspectorate. The formulation and enforcement of regulations for soil and water conservation especially in erosion and flood prone areas is highly essential at the moment.

There is need for the construction of more drainage channels and the rehabilitation of old drainage system within the study area.

Adequate funds should be provided by the government to carry out studies on annual rainfall input and the prediction of the resultant flooding and erosion problems in the study area.

There is therefore, the need for coordination between the various relevant expertise located in the Agencies of Government to be strengthened and improved upon for effective networking and integrated approach in the provision of more drainage system, control and management of flooding and erosion problems in the area.
Government at all levels should strive to provide funds to redress the already initiated and future problems of flooding and erosion in the study area.

At present, all levels of Government should place more emphasis on the construction of flood and erosion control works, whenever there is flood and erosion menace. Although, the incorporation of the biological aspect with that of flooding and erosion control measures has proved to be somewhat effective, a more sustainable control of flooding and erosion problem should be advocated.

The Town Planning Authority should be active in discouraging property construction on areas liable to flooding, and quick response to flooding and erosion hazards in the study area, as this would help in reducing the incidence of flooding and erosion.

Most of the untarred roads, if not all, should be properly tarred in the study area, so as to avert the prevailing problems of flooding in the area.

It was equally revealed that the proper land use and planning, and the enforcement of proper refuse disposal system in the area will help in controlling the problem of flooding in the study area.

Road networks should be constructed parallel to the main slope direction or to stream channel in order to prevent the creation of new water channels against the general landscape trend, which usually end-up in gullies that cut off the roads.

Roads should be designed and constructed in such a way as to ensure that sidewalks are paved or tarred. The paved roads must be made to merge with carefully designed drainage lines (gutters).

The adoption and enforcement of Urban Master Plan development strategy in the study area to ensure equitable and sustainable development of all spheres, as well as to avoid environmental leakages is highly paramount at the moment.

\section{$\mathrm{X}$ CONCLUSION}

A healthy environment is critical to the effective implementation of environmental strategies. This informed the high premium, which we place on environmental protection issues. It is also vital to the attainment of the goals and targets of global initiatives to which Nigeria is a party, especially the Millennium Development Goals. We must recognize the prime place of rebuilding and expanding our critical infrastructure, just as we cultivate a determined effort to rapidly regenerate our national economy. We also should be determined to create and sustain the macroeconomic prerequisites of a globally competitive and acceptable environment friendly economy. By the same token, we should be conscious of the imperative of ensuring that our economic regeneration efforts are environmentally sustainable.

Although, it is important to make laws, it is more important for the laws to be respected and enforced. It is therefore our collective duty, to us and to future generations to ensure that all regulations and laws regarding the environment are respected. A clean and safe environment is our desire, let us therefore join hands to minimize environmental degradation and halt further damage or totally reverse the processes that lead to environmental degradation, to ensure that Nigeria is clean, safe and pollution free. 


\section{ACKNOWLEDGMENT}

The Author wish to express his profound gratitude to God Almighty, for the good health and provision of needed resources during the course of this research work. Also, to the Management and Members of Staff of Ekiti State University, Ado-Ekiti, Nigeria, for all the support and assistance during the course of this research work and to Tope ID Computers for the typing of the Manuscript. I am sincerely very grateful.

\section{REFERENCES}

[1] M.T. Okorodudu-Fubara, Law of Environmental Protection: Materials and Text, Ibadan, 1998

[2] Y. Oruwari, Introduction to Environmental Sciences. HSIS Publishing Limited. Cited in Abegunde, B., Adebayo, W. O., and Ogunlade, F. (2007): Environmental Law and Development. AdoEkiti, Petoa Educational Publishers, 2001

[3] F.I. Afolabi " "A Crucial Assessment of Environmental Problems in Ondo State. Selected Examples and the Way Forward". An Environmental Sensitization Workshop Organized by the Ondo State Government Ministry of Special Duties, Department of Environmental and Mineral Resources, Akure, 2005

[4] J. Glasson, R. Therivel, and A. Chadwick, An Introduction to Environmental Assessment, Principles, Procedures, Process, Practices and Prospects (2nd Edition) New York, Pergamon Press, 1999

[5] B. Abegunde, W.O. Adebayo, and F. Ogunlade, Environmental Law and Development. Ado-Ekiti, Petoa Educational Publishers, 2007

[6] V. Ukeogo, Transnational Business Ethics, Government Policies and the Crisis of Pollution and Underdevelopment in the NigerDelta: Environmental Problems of Niger Delta. Edited by A Osuntokun, 2006, Page 202.

[7] Federal Environmental Protection Agency Act (2004) Retrieved from www.onlingenigeria.com, 2020

[8] M.A. Ajomo, Judicial Response to the Protection of the Nigerian Environment and its Citizenry Paper Presented at the River State Law Conference, 1989, 25-27, Page 4.

[9] U.M. Yar'Adua, Report of the First National Stake Holders Forum on the New Mechanism for Environmental Protection and Sustainable Development in Nigeria. Abuja, 2007

[10] World Bank Report (CEA) National Environmental Standards and Regulatory Enforcement Agency, 2006

[11] O.O. Osibanjo, the Importance of Effective Compliance and Enforcement of Environmental Regulations and Standards. National Environmental Standards and Regulatory Enforcement Agency (NESREA) Quarterly Magazine, Report, 2009, Page 17 \& 21

[12] C.M. Peter, Taking Environment Seriously: The African Chartered Human and Peoples Rights and the Environment. Revenue Africale De Droitsde 11. Home, Vol. 3, No. 4, 1993,Pp. 42-49.

[13] A. Saba, Annual Technical Report. Reporting Period: January to December, 2009.Island; Saba. Protected Area Management Foundation. Saba Conservation Foundation, 2009.

[14] P.B. Eregha and I.R. Irughe, Oil induced Environmental Degradation in the Nigeria's Niger Delta: The Multiplier Effects. Journal of Sustainable Development in Africa. Volume 11, N0 4, Pp 160-175. Federal Environmental Protection Agency (1998) A Publication of the Federal Environmental Protection Agency, Nigeria, 2009.

[15] S.I. Omofonmwan and L.O Odia, Oil Exploitation and Conflict in the Niger Delta Region of Nigeria. Journal of Human Ecology. Vol. 26, N01, 2009, Pp. 25-30

[16] M. Rosenberg, Geography Guide. Accessed June, 2011www.wikipedia.org/wiki/geography-of-nigeria, 2011.

[17] Geography of States in Nigeria. www.zodml.org.,Discourse/Nigeria/FactsaboutNigeria, 2013.

[18] M.D. Park, Earth Observation: Researchers Seeing Double on African Monsoons. New York, Space Media Network Promotions, 2004.

[19] United Nations Environmental Protection (UNEP), United Nations Conventions on the Law of the Sea 10th December, Montego Bay. Environment and Planning Law Review. A Quarterly Journal on Environment and Planning Law. Vol. 2, No.1, 2005, Pp. 123.

[20] United Nations Development Report (UNDP), Niger Delta Development Human Report, 2006.

[21] United Nations, the Human Environmental, World Mark: Encyclopedia of the Nations. World Mark Press Limited, 2009.
[22] B.Y. Osifeso, The Changing Role of Law in the Emerging World Environment Order. A Paper Presented to 1999 Set. LLM Class on Environmental Law, Obafemi Awolowo University, OAU, Ile-Ife, 1999.

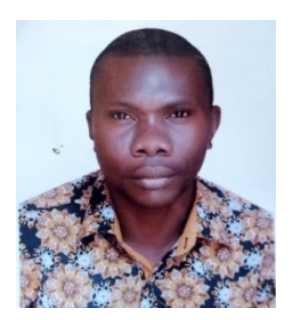

JEGEDE, Amen Osamede is a lecturer in Ekiti State University, AdoEkiti, Nigeria. He holds MSc. in Geography and Planning Science (Environmental Management and Planning, Option) from University of Ado-Ekiti, Nigeria (Now, Ekiti State University, Ado-Ekiti, Nigeria, and $\mathrm{PhD}$ in Geography and Planning Science(Option in Environmental Laws) from Ekiti State University, Ado-Ekiti, Nigeria.

He has about 10 years in teaching and research. His areas of specialization are Social Statistics, Environmental Management and Planning and Environmental Laws, among others.

Dr. Jegede is a member of the Association of Nigerian Geographers, Hospitality and Tourism Management of Nigeria, and a Fellow at the Certified Institute of Hospitality Tourism and Management. He has many scholarly publications to his credit. 